\title{
THE FRACTURED FLINTS OF THE EOCENE "BULL-HEAD" BED AT COE'S PIT, BRAMFORD NEAR IPSWICH.
}

\author{
By the President (J. REID MOIR, F.R.A.I.)
}

Read at Norwich, October I3th, rgr3.

During the past few years discoveries of flaked flints of various kinds have been made in certain pre-river-valley deposits in Suffolk and Norfolk, and the discoverers of these specimens have had to meet, from some quarters, a very determined opposition to the view that these stones have been fashioned by man at periods long anterior to those in which the earliest Palæolithic implements were made. The details of the discovery of these flaked flints have already been made public in various scientific publications, ${ }^{1}$ and papers have been published giving the discoverers' reasons for believing them to be of human manufacture, and their opponents' reasons for looking upon them as purely natural productions.

In the last part of our Proceedings I gave an account of the series of experiments I had carried through with flints subjected to natural pressure and percussion, ${ }^{2}$ and endeavoured to show how the flaking produced by these experiments differed from that seen upon undoubted examples of human handiwork. The chief objection brought against my conclusions was that it is impossible to imitate the forces of Nature which act upon flints by shaking stones in a sack and fracturing them by pressure in a screw-press, and I confess that at first sight this appears to be a very weighty argument and one difficult to refute. But a close and searching examination of these "mighty forces of Nature," a phrase often used with marked effect upon an uncritical audience, will, I think, show that they are largely inoperative upon flints, and that if they are too "mighty" the flint succumbs and is shattered to fragments.

It therefore seems that in a state of nature flints can only be subjected to a certain amount (hy no means large) of direct pressure or force of blows, and it is highly probable that these

1 Lankester, Sir Ray. "On the discovery of a novel type of flint implement below the base of the Red Crag." Phil. Trans., Series B., vol. 202, pp. $283-336$.

Moir, J. Reid. Antea, pp. 17-43, $171-184$, 307-319, 368-374:

Clarke, W. G. Antea, pp. $160-8$.

Moir. J. Reid. "Pre-Palæolithic Man." Bedrock, Vol. 2, pp. 165-176, July, 1913.

Moir, J. Reid. "A description of the Pre-Palæolithic implements." Bedrock, Vol. 2, pp. 490-495.

F. N. Haward. Antea, pp. 185-193, 347-359.

Moir, J. Reid. "The making of a rostro-carinate flint implement." Nature, Nov. 21st, 1912, p. 334.

2 Antea, pp. 171-184. 
amounts can be and were imitated in my experiments. I also concluded, and I still hold to the same opinion, that pressure and blows are to all intents and purposes alike, whether brought into action on the one hand in a letter-press or a geological deposit, or on the other in a violently shaken sack, or on a sea beach, or in a fast running river. The exact conditions might vary slightly, but the general result would be the same.

An examination of stones flaked by wave action on sea beaches soon convinced me that these fractures are very similar to those produced upon the flints in my sack experiment, where the flakes which form the usual pseudo-sinuous edge are removed at diverse angles, and of that short and "deep" variety so usual with "natural" flaking. The flakes which have been removed from the beach specimens also show in nearly every case pronounced ripple marks demonstrating they have been removed by oblique "jarring" blows to the edge of the flint, and finally the battering of the edge itself and prevalence of incipient cones of percussionon the surfaces of the stones, where blows which did not remove flakes had impinged, completed the resemblance to those I had flaked experimentally in my sack.

Thus having recognised the main characteristics of flaking produced upon flints by fortuitous blows, it remained to discover and examine some geological deposit where stones were being tlaked by natural pressure, if such a deposit existed, and to compare such fractures with those produced in my presses.

The idea of examining the layer of green-coated flints, generally known as the "Bull-head" bed, at the base of the Eocene strata was first suggested to my mind by the paper published by M. H. Breuil in L'Anthropologie $e^{8}$ in which he describes and figures numerous flaked flints found by him in the lower Eocene deposits at Belle Assise in France. These flints, the drawings of which show a great resemblance to the work of man, are said by the Abbe Breuil to have been all produced by natural pressure in the beds in which they are now found, and the inference is drawn that as Nature cun flake flints in this wayit is unsafe to regard any specimens flaked in a primitive manner as being of human origin.

When I read this article, I found myself unable to believe it to be possible that these flints had been flaked by pressure, lying as they do below a considerable depth of fine stoneless sand, as some experiments I had carried out had shown in the most conclusive manner that even an inch or two of sand will protect the thinnest flake from the effect of very heavy pressure.

Thus while I would now like it to be known that in my opinion M. Breuil was right in naming the force responsible for the flaking on the flints in the Eocene stratum, yet I do not agree with him that this pressure has ever operated or is operating now through the sand which overlies this bed. But it

3 Breuil H. "Sur la présence d'Éolithes à la base de l'Éocène Parisien."-L'Anthropologie. 
is my opinion that slight pressure was brought to bear upon these flints before the deposition of the sand. The freshness of some of the fractures upon the Eocene stones has, I think, misled M. Breuil into concluding that they must have been broken quite recently. But as these flints lie in a deposit very rich in clay, the fresh appearance of the fractured surfaces affords no certain evidence that such fractures are recent.

It is obvious, however, that the flints in the Eocene bed on the surface of the Chalk at the pit at Bramford I have been investigating, have been fractured by pressure, ${ }^{4}$ and I now propose to describe this pit and the various broken flints which occur in the "Bull-head". bed there, and endeavour to show how, in my opinion, these specimens difter entirely and fundamentally from those in later deposits which are looked upon by some prehistorians, including myself, as humanly fashioned. I also propose to demonstrate the great resemblance these specimens bear to those fractured in my presses, and thus to indicate the value of work done with such appliances.

The large excavation which has afforded me such excellent opportunities for examining the Eocene stratum containing the flints under discussion is situated on the left bank of the river Gipping, and about two miles north-west of the town of Ipswich. The section exposed is one of the finest in Suffolk, and shows about 70 to 100 feet of white chalk on the even surface of which occurs the bed, about 2 feet in thickness, of green coated flints impacted in a matrix of homogeneous clay of a greenish colour, and averaging 8 feet in thickness. Surmounting this bed are upwards of 40 feet of deposits comprising Thanet and Reading Beds, London Clay, decalcified Crag, and Middle Glacial Sand and Gravel. (Plate XCIX.)

As I have observed, the surface of the chalk is quite level at this spot, and there cannot, I think, be any question as to the superjacent beds having slipped and thus caused pressure to be brought to bear upon the Eocene flints. Moreover these upper beds are remarkably free from any signs of movement or contortion, and it appears that they have remained stationary and in situ since the time of their deposition.

Owing to the manner in which the pit is worked it is generally possible to find several yards of the undisturbed "Bull-head" bed exposed, and I have thus been able to extract these flints carefully from their matrix, and to see exactly their surrounding conditions.

In the article quoted above, M. Breuil gives a detailed description of the exact method in which the flints at Belle Assise have been fractured, but not having seen any of his specimens in situ I cannot say from personal observation whether his conclusions are correct.

4 My best thanks are due to Mr. Coe, the owner of the pit, and to his foreman, Mr. Jackson, for their kindness and courtesy during my - investigations. 
I have not yet, however, been able to find definite evidence that the flints at Bramford have been fractured in the manner he describes, and after a prolonged investigation I cunfess I am at present unable to describe the exact manner in which the pressure has acted which has broken the specimens there, but the flints are extremely numerous and closely packed together (in this respect differing very markedly from those in later deposits) (Plate C.), and if pressure was brought to bear upon the bed which contains them fractures must inevitably take place.

One thing, however, has become clear to me, and that is that these Eocene flints must differ in their nature from others in other deposits in that they are more easily fractured. Whether this liability to fracture is due to the nature of the material in which they have been so long embedded I cannot say, but an examination of them in situ makes it obvious that they are in a condition best described as "soft," as a light blow with any hard object will cause many of them to break up. Experiments also have demonstrated that much less pressure is required to break them than is needed to break those from the Sub-Crag and other horizons. This conclusion is supported moreover by the appearance of the broken flints themselves, as though fractured by pressure no scratches of any sort are to be seen upon them, nor do any of them show the slightest signs of having been heavily crushed. It is clear that if any heavy pressure had acted upon these flints they would have been forcibly ground against each other, and scratches and crushing upon some portion of their surfaces inevitably produced.

But as such is not the case the flints must have been subjected to only a very slight pressure, and in consequence must have been in a condition of "softness" to be affected by it. It seems therefore certain that these Eocene flints when in situ are in the first place abnormal and unlike those from other horizons, and it is also clear that the underlying bed of resistant chalk has afforded the necessary hard surface for this pressure to act successfully. The evidence of their having fractured in situ by pressure is clear and unmistakable, as it is possible to find specimens with flakes detached though not removed from the parent block, and apart from any other evidence it is obvious that percussion cannot have been the fracturing agent, because then the flake, when struck, would in nearly every case fly off, and not be found in association with the parent nodule. Also no incipient cones of percussion such as would be produced by fortuitous blows are to be seen upon these specimens.

The flaked flints, when a large series of them is examined, are seen to be of fantastic shapes such as would be expected to be produced by the blind, unguided forces of Nature. Occasionally, a form appears reminiscent of the work of man, but this resemblance is only superficial and will not bear a really careful and enlightened examination. The great majority of the fractured 
flints have broken from the projecting points which are so frequent on these specimens, and this peculiarity, coupled with the "softness" I have mentioned, has produced the curious haphazard appearance of the broken nodules.

Out of 9:3 specimens collected at random only two show any resemblance, and that only a superficial one, to forms of flints flaked by man. One is a rough, uneven, cylindrical nodule fractured roughly at one end and at the other flaked by pressure at its point into a fantastic likeness to a pointed implement. The other example simulates a very small cone, like those of the Aurignac-Palæolithic-Cave period. The remaining specimens comprise flakes and roughly broken pieces of flint, which have had one or two odd flakes removed from projecting points, and are of quite meaningless shapes.

It is generally the flints having these projections which have been flaked, the rounder nodules more often escaping the fracturing process. But as the former type of nodule is so numerous, this Eocene bed contains a large number of flakes with the original cortex of the flint left upon one side of them, and a great many can be collected during a day's search.

These flints I have found differ from those discovered at Belle Assise by M. Breuil, in that " retouching " or edge-flaking is almost entirely absent unon them. Also I have been quite unable to divide the Bramford flints into types, and even M. Breuil, out of a very large number of specimens, was apparentily only able to find a few showing a similar form and method of flaking.

The broken surfaces of the Eocene flints are generally quite fresh in appearance, ${ }^{5}$ that is to say are not patinated or stained in any way, and exhibit a dull nor-lustrous texture which is peculiar. This is in some cases due to the method of fracture of the flint, and in others to their having lain in a hard, impervious clay.

Small mirrors of polish are present on many of the specimens, and as I have sometimes observed these on freshly broken flints from the Chalk, I. am led to believe they represent small inclusions of some sort in the flint, and are not necessarily due to causes which have acted since the stone was broken.

When a series of the Eocene flints is put out and compared with those found below the Red Crag or in the Middle Glacial Gravel or Chalky Boulder Clay, it is at once clear that they differ completely from the flaked flints from these later deposits. The Eocene specimens have all frartured along the lines of least resistance, as is always the case with pressure flaking, and in consequence ripple marks and fissures are very seldom developed.

These characteristics, described fully in my paper dealing with the fracture of flint, are very often to be observed upon the

5 There are a very few specimens which show a glazed surface, and are in a manner "patinated." These may or may not be older than the "bull-head" bed, but by their appearance I feel confident they too have been fractured by pressure. 
surfaces of a flint fractured by blows, because in this case the direction of the blows has forced a line of cleavage through the flint which has not followed the line of least resistance. The result is that the flint is jarred and ripple-marks produced, and having been, as it were, forcibly torn asunder, fissures are also developed upon the surfaces of the flakes removed.

I would lay great stress upon these differences which are apparent between flints fractured by pressure and percussion, as by means of such observations it is possible when a good series of specimens is seen to decide by what means they have been broken.

The two methods of fracture, too, apparently produce two diftering surfaces; and I have often observed that a flake from a flint removed by percussion will differ in appearance from another removed by pressure from the same stone. I would liken this difference to that to be seen upon two apples, one of which has been broken in half while the other has been cut with a knife. In the former the line of least resistance is followed and a rough flocky surface is produced. In the latter the line of cleavage is determined by the user of the knife, and a surface of a different texture results. The pressure flakes are generally not so glossy as the others, and this is certainly the case with the fractured Eocene specimens which have been broken by pressure and are in consequence dull. The bulbs of percussion also of the Eocene flints never show "striking platforms" (that is, the flat surface produced by man to enable him to remove a properly formed flake), and are never normally developed, being flat and insignificant.

Again I have found in the Eocene bed flakes which exhibit two bulbs at opposite ends, showing where pressure and resistance have acted, and which can only be produced by pressure. When, too, I find "retouching" or edge flaking on these flints it is obvious that this has been produced by pressure, as the individual flakes have not cut deeply into the flint, but are simply thin scalings removed from the edge.

Thus the flints from the "bull-head" bed are typically natural, possessing no definite forms and not capable of being separated into types. The flaking has obviously been produced by natural pressure, and even to a casual observer there is no sign of that manipulation and overcoming of difficulties in flaking such as is plainly seen upon humanly struck flints. We are evidently dealing with the work of Nature, and as would be expected in the case of flints, she has acted blindly and without purpose.

When, however, we turn to the Sub-Crag, Middle Glacial, and Boulder Clay specimens an extraordinary difference is observable, and the most uneritical eye can at once see the imprint of human intention upon them.

Though the flaked flints from these three horizons differ markedly from each other we see definite types recurring again 
and again in each group, and a gradual improvement in flaking in progress. The elaborately planned rostro-carinate appears first below the Red Crag, and is fashioned by the large surfaces of fracture of that period. In the Middle Glacial Gravel it is made by much more delicate flaking, and is altogether more graceful in its outlines. When the Boulder Clay specimens are examined it appears that the rostro-carinate is degenerating in make and being replaced by a more Chelles-like type of implement.

The series of borers, scrapers, etc., of the Sub-Crag horizon are each made in their own particular manner, and so it is with the various groups of implements from the Middle Glacial Gravel, and those from the Chalky Boulder Clay. A study also of the actual flaking of these specimens will soon show what a difference exists between them and those from the Eocene bed I have described. In each group "striking platforms" have been produced before many of the flakes were removed, the flints having generally been fashioned by skilful vertical blows, and the "human touch" so familiar to those who handle large numbers of flint implements is most plainly visible.

The flakes which have been struck off also occasionally exhibit on their surfaces minor conchoidal ripplings such as are developed when the blow which detached the flake was not quite vertical, and groups of fissures radiating from the point of impact are nearly always present. None of the specimens show two bulbs such as I described as being caused by resistance and pressure, and in short there is a very real and fundamental difference between the fractured flints from the Eocene "bullhead" bed, and from the later deposits I have described.

When, however, I compare these Eocene examples with those I have fractured in my presses it becomes at once apparent that the two series are almost identical. The experimental specimens exhibit the same dull, lustreless surface, the same pseudo-bulbs of percussion, the same lack of ripple marks and fissures, and the same large thin transparent plates of flint upon the broken surfaces. Double bulbs are also of frequent occurrence demonstrating that the flint has been fractured by placing it upon the floor of a press and forcing the ram upon its upper surface.

The retouching which I have produced by pressure exhibits the same characteristics as those present upon some of the Eocene flints, the individual flakes having only just been scaled off from the edge and not cut more deeply into it, as is the case with edge work produced by human blows. No "striking-platforms" are to be seen upon the flakes removed in my pressure experiments, and altogether the two series are so alike as to make it in the highest degree probable that both have been fractured by the same agency. I have myself flaked by blows some of the fractured flints from the Eocene bed, so that the two sorts of flaking can be compared on the eame sr ${ }^{n i}$ men. I have also flaked some of 
the flints by pressure, for comparison with the natural fracturing on the specimens.

It has always been my opinion that continued experiments are the only satisfactory means of getting to know anything really definite about the fracture of flint. Other investigators, however, thought that these experiments did not represent the forces of Nature, and that no really valuable conclusions could be drawn from them, But I did not publish my conclusions until I had very carefully thought the matter out, and now that I have been able to examine flints flaked by natural percussion and pressure, I consider I was fully justified in my belief that my experiments were of value.

I was advised to examine sections and places where Nature was undoubtedly flaking flints. I have now made an attempt to do this, and $\mathrm{J}$ think it will be conceded the results up to the present show that such fractured stones differ very markedly from those which I have always regarded as having been fashioned by different races of pre-palæolithic men.

It is infortunately impossible to show by any photographs or drawings the various characteristics of the Eocene flints described in this paper, but all the specimens are in my possession and will be gladly shewn to anyone desirous of seeing them.

\title{
NOTES ON THE IMPLEMENTS FROM THE FACTORY
} SITES AT PEPPARD, OXON.

\author{
By A. E. PEAKe, M.R.C.S., L.R.C.P.
}

Read at Norzench, December 8th, 1913 .

Since reading a paper before the Archæological Institute of Great Britain and Ireland in February, 1913, on the two factory sites at Peppard, Oxon, we have carried out further excavations, and I propose to give a brief account of the new implements found there, and to discuss the evidence as to the date arrived at as a result of the whole work. Sections of the sites and a map showing their position were given in that paper, and 28 of the implements illustrated.

The deeper site (Site 1) was re-opened by Mr. Reginald Smith, F.S.A., of the British Museum, in October, 1913, and some of the problems connected with it cleared up. This site was then found to be an open pit, similar to a modern chalk pit, with a pathway leading into it from the lowest level, $8 \mathrm{ft}$. across and $7 \frac{1}{2} \mathrm{ft}$. long. The floor of this adit formed a gently inclined plane to the bottom of the pit, heing covered at the entrance with $2 \frac{1}{2} \mathrm{ft}$. of rainwash. This method of approach to the mine is what one would expect from its situation on the slope of a hill. It differs 
Plate XCIX.

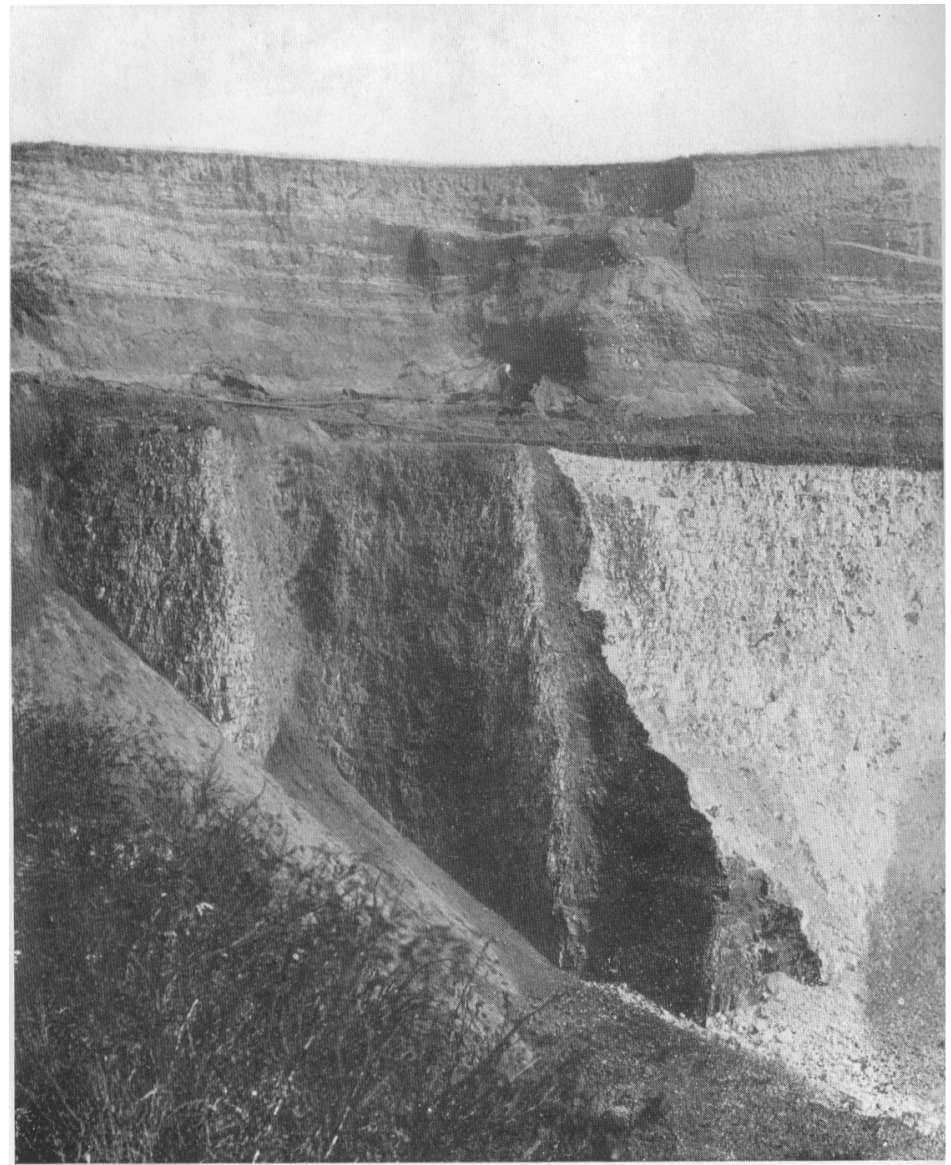

General view of Coe's Pit, Bramford. The Eocene Flint bed rests immediately upon the chalk. 
Plate C.

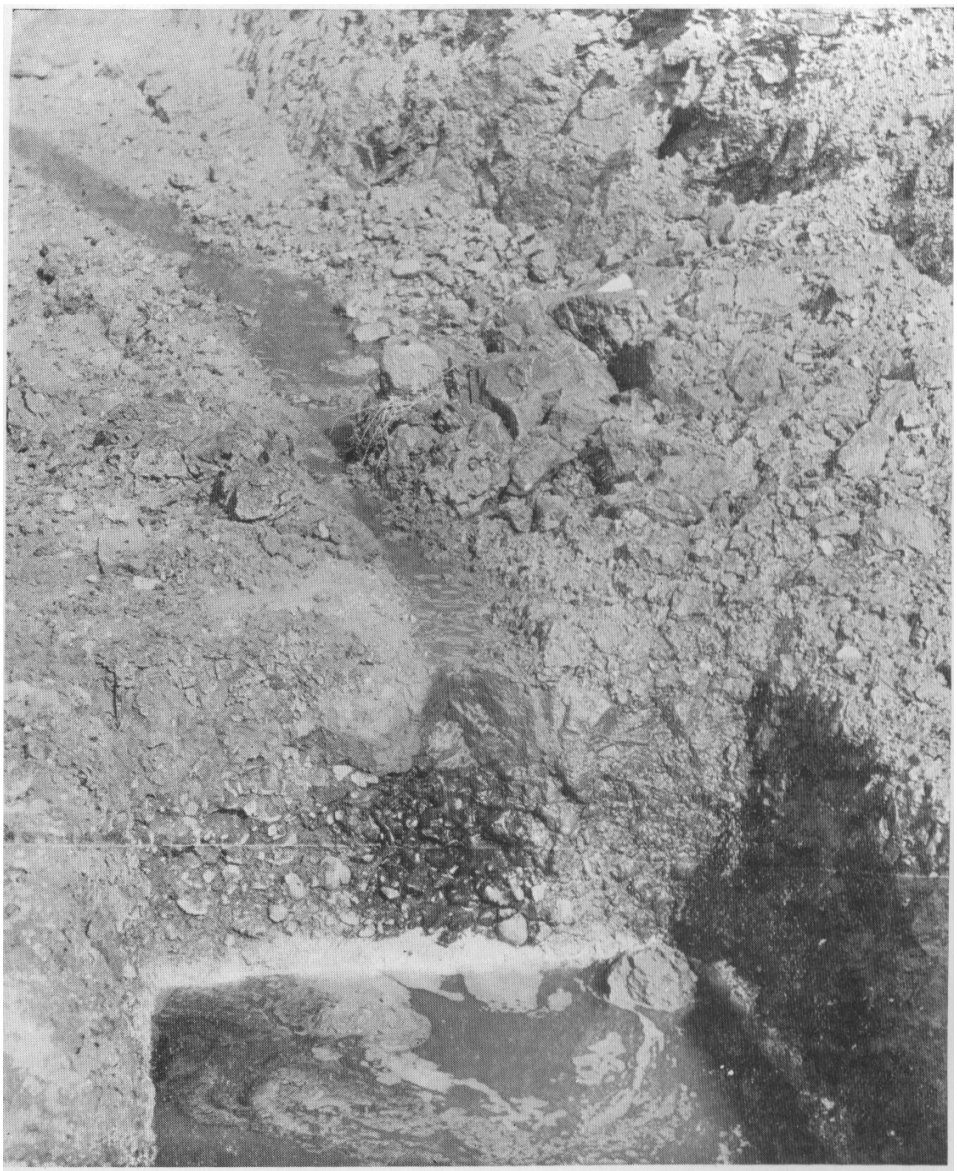

View showing the closely packed mass of Eocene Flints resting upon the surface of the chalk at Coe's Pit, Bramford. 